Canadian

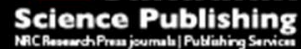

Canadian Journal of Microbiology Revue canadienne de de microbiologie

\title{
Characterization of the VP39 Envelope Protein from Singapore grouper iridovirus
}

\begin{tabular}{|r|l|}
\hline Journal: & Canadian Journal of Microbiology \\
\hline Manuscript ID & cjm-2015-0118.R3 \\
\hline Danuscript Type: & Article \\
\hline Complete List of Authors: & $\begin{array}{l}\text { Honglian, Zhang; School of Life Sciences, Sun Yat-sen University, State } \\
\text { Key Laboratory of Biocontrol; Guangdong Ocean University, College of } \\
\text { Fishery } \\
\text { Sheng, Zhou; South China Sea Institute of Oceanology, Chinese Academy } \\
\text { of Sciences, Key Laboratory of Tropical Marine Bio-resources and Ecology } \\
\text { Liqun, Xia; Guangdong Ocean University, College of Fishery } \\
\text { Xiaohong, Huang; South China Sea Institute of Oceanology, Chinese } \\
\text { Academy of Sciences, Key Laboratory of Tropical Marine Bio-resources and } \\
\text { Ecology Huand } \\
\text { Youhua, Huang; South China Sea Institute of Oceanology, Chinese } \\
\text { Academy of Sciences, Key Laboratory of Tropical Marine Bio-resources and } \\
\text { Ecology } \\
\text { Jianhao, Cao; School of Life Sciences, Sun Yat-sen University, State Key } \\
\text { Laboratory of Biocontrol } \\
\text { Qiwei, Qin; South China Sea Institute of Oceanology, Chinese Academy of } \\
\text { Sciences, Key Laboratory of Tropical Marine Bio-resources and Ecology }\end{array}$ \\
\hline Keyword: & \begin{tabular}{l} 
Singapore grouper iridovirus(SGIV), VP39, Late gene, Envelope protein \\
\hline
\end{tabular} \\
\hline
\end{tabular}


Characterization of the VP39 Envelope Protein from Singapore grouper iridovirus

Honglian Zhang ${ }^{1,3}$, Sheng Zhou ${ }^{2}$, Liqun Xia ${ }^{3}$, Xiaohong Huang ${ }^{2}$,Youhua Huang ${ }^{2}$, Jianhao Cao ${ }^{1}$, Qiwei Qin ${ }^{2 *}$

${ }^{1}$ State Key Laboratory of Biocontrol, School of Life Sciences, Sun Yat-sen University,135 West Xingang Road, Guangzhou 510275, PR China

${ }^{2}$ Key Laboratory of Tropical Marine Bio-resources and Ecology, South China Sea Institute of Oceanology, Chinese Academy of Sciences, 164 West Xingang Road, Guangzhou 510301, PR China

${ }^{3}$ College of Fishery, Guangdong Ocean University, Zhanjiang 524088, Guangdong, PR China

\section{*Corresponding author:}

Qiwei Qin, Ph D., Professor,

Key Laboratory of Tropical Marine Bio-resources and Ecology, South China Sea Institute of Oceanology, Chinese Academy of Sciences, 164 West Xingang Road, Guangzhou 510301, China

E-mail: qinqw@scsio.ac.cn, Tel \& Fax:+86-20-89023638 


\begin{abstract}
Singapore grouper iridovirus (SGIV) is a major pathogen that causes heavy economic losses to the grouper aquaculture industry in China and Southeast Asian countries. In the present study, a viral envelope protein, VP39, encoded by SGIV ORF39L, was identified and characterized. SGIV ORF39L was found in all sequenced iridoviruses, and is now considered to be a core gene of the family Iridoviridae. ORF39L was classified as a late gene during in vitro infection using reverse transcription-polymerase chain reaction, western blotting, and a drug inhibition analysis. An indirect immunofluorescence assay revealed that the VP39 protein was confined to the cytoplasm, especially at viral assembly sites. Western blot and matrix-assisted laser desorption/ionization-time of flight tandem mass spectrometry analyses suggested that VP39 is an envelope protein. Immunogold electron microscopy further confirmed that VP39 is a viral envelope protein. Furthermore, a mouse anti-VP39 polyclonal antibody exhibited SGIV-neutralizing activity in vitro, suggesting that VP39 is involved in SGIV infection. Taken together, the current data suggest that VP39 represents a conserved envelope protein of iridoviruses that contributes to viral infection.
\end{abstract}

Keywords: Envelope protein; Late gene; Singapore grouper iridovirus (SGIV); VP39 


\section{Introduction}

Iridoviruses are large, icosahedral, double-stranded DNA viruses. They exist in two forms: non-enveloped particles $120-180 \mathrm{~nm}$ in diameter and enveloped particles that result from budding from the plasma membrane. In addition to the external envelope, some iridoviruses contain a fringe of fine fibers (fibrils) that extend outward from the capsid subunits (Chinchar et al. 2011). Non-enveloped particles are composed of three distinct layers: an outer capsid composed of multiple copies of an $\sim 50 \mathrm{kDa}$ major capsid protein (MCP), an internal lipid membrane possibly derived from the endoplasmic reticulum (ER) or other cellular membranes, and an inner core containing the viral genome and associated viral-encoded proteins. Although both forms are infectious, enveloped virions were shown to have higher specific infectivities (Braunwald et al. 1985; Chinchar et al. 2011; Yan et al. 2000).

Iridoviridae includes five genera, Ranavirus, Megalocytivirus, Lymphocystivirus, Iridovirus, and Chloriridovirus (Jancovich et al. 2012). Iridovirus infection and transmission among insects, fish, amphibians, and reptiles have caused great economic losses in the aquaculture industry, as well as ecological destruction (Gray et al. 2009; Lesbarrères et al. 2012; Schock et al. 2010; Whittington et al. 2010).

Singapore grouper iridovirus (SGIV), one of the major viral pathogens of grouper aquaculture, has been characterized as a member of the Ranavirus genus (Qin et al. 2001, 2003). The genus Ranavirus is composed of at least six recognized species: Ambystoma tigrinum virus, Bohle iridovirus, Epizootic hematopoietic necrosis virus, European catfish virus, Frog virus 3, the type virus of the species, and Santee-Cooper 
ranavirus (King et al. 2012). SGIV enters grouper cells via the clathrin-mediated endocytic pathway and macropinocytosis in a $\mathrm{pH}$-dependent manner, and it is transported along both microtubules and actin filaments (Wang et al. 2014). Replication involves the nuclear and cytoplasmic compartments and utilizes host and viral enzymes. SGIV induces non-apoptotic cell death in spleen cells in vitro, and causes enlargement of the spleen with hemorrhaging in vivo (Huang et al. 2011). SGIV infection has a greater than $90 \%$ mortality rate in grouper and sea bass (Qin et al. 2003). However, despite the high mortality rate, no effective treatment for SVIG infection is available.

To prevent serious iridovirus infections, studies have been conducted that used polyclonal or monoclonal antibodies to discover antigenic structures in iridoviruses (Wan et al. 2010). Viral surface antigens are localized mainly to the outer envelope or capsid surface of virions (Cheng et al. 2006; Monini and Ruggeri 2002). Proteomics and bioinformatics are believed to be efficient approaches in the field of functional genomics, and they have been widely used to analyze viral structural proteins. Currently, the genome sequence, viral transcription program, and global landscape of structural proteins of SGIV have been investigated (Song et al. 2004, 2006; Teng et al. 2008). SGIV VP39 was revealed to be a conserved iridovirus core gene, and it was predicted to be a serine/threonine protein kinase (Eaton et al. 2007) that was able to phosphorylate recombinant SGIV ORF075R (Wang et al.2008). In this study, VP39 was identified and shown to be a viral envelope protein, and its localization was determined. Recombinant VP39 (rVP39) was expressed in Escherichia coli. An 
antibody against rVP39 was developed, and its ability to inhibit SGIV infection was investigated. All these data will provide new insights into our understanding of the structural protein composition of SGIV.

\section{Materials and methods}

\section{Virus and cell cultures}

SGIV (strain A3/12/98 PPD) was propagated on grouper spleen (GS) cell monolayers as previously described (Qin et al. 2001). SGIV was stored at $-80^{\circ} \mathrm{C}$ until use. GS cells were derived from the orange-spotted grouper, Epinephelus coioides (Qin et al. 2006) and were cultured at $25^{\circ} \mathrm{C}$ in Leibovitz's L-15 medium containing 10\% fetal bovine serum (Gibco-BRL, Grand Island, NY, USA) and subcultured at a ratio of 1:3 every four days.

\section{Sequence analysis}

The sequence of the SGIV VP39 gene was analyzed against the National Center for Biotechnology Information (NCBI) database using the Basic Local Alignment Search Tool (BLAST) server (http:// www.ncbi.nlm.nih.gov/blast). Motifs contained in VP39 were predicted using the ExPASy website (http://prosite.expasy.org /scanprosite). Conserved domain prediction was performed using the Simple Modular Architecture Research Tool (SMART) program (http://smart.embl-heidelberg.de/). The transmembrane sequence of VP39 was predicted using the TMpred method (http://ch.embnet.org/software/TMPRED_form.html). Nuclear localization signals 
(NLSs) and nuclear export signal (NESs) of VP39 were predicted using the NLS_Mapper Server (http://nls-mapper.iab.keio.ac.jp/cgi-bin/NLS_Mappery.cgi) and NetNES Server (http://www.cbs.dtu.dk /services /NetNES/), respectively. Multiple amino acid sequence alignments were performed using ClustalX 1.83 and edited with GeneDoc software. The phylogenetic tree was established using MEGA 5.1 software, with the neighbor-joining (NJ) method and bootstrapping (1000 replicates). The GenBank accession numbers of VP39 homologs from different iridoviruses used in the phylogenetic analysis are listed in Table 1.

\section{Prokaryotic expression, protein purification, and antibody preparation}

The recombinant plasmid pET-rVP39 was transformed into E. coli BL21 cells, and His-tag fusion protein expression was induced with $0.7 \mathrm{mM}$ isopropyl $\beta$-D-1-thiogalactopyranoside(IPTG) at $37^{\circ} \mathrm{C}$ for $4 \mathrm{~h}$. The fusion protein was purified from inclusion bodies under denaturing conditions using the His-Bind Purification kit (Novagen, Merck KGaA, Darmstadt, Germany) according to the manufacturer's instructions. Briefly, inclusion bodies were dissolved overnight at $4^{\circ} \mathrm{C}$ in $8 \mathrm{M}$ urea $(\mathrm{pH}$ 8.0) with gentle agitation, and then the solution containing the recombinant protein was mixed with Ni-NTA His-Bind Resin (Novagen, Merck KGaA, Darmstadt, Germany) overnight. The mixture was loaded onto a column, washed with $8 \mathrm{M}$ urea ( $\mathrm{pH} 4.5$ ), and then eluted with $8 \mathrm{M}$ urea ( $\mathrm{pH}$ 3.0). To obtain antibodies against SGIV rVP39, purified, was mixed with an equal volume of Freund's adjuvant (Sigma-Aldrich, St. Louis, MO, USA) and $50 \mu \mathrm{g}$ was injected hypodermally into 
mice at 7-day intervals. Freund's complete adjuvant was used in the first injection, and Freund's incomplete adjuvant was used in all subsequent injections. The antiserum was collected after the fifth immunization and used for subsequent immunoassays.

\section{Reverse transcription-polymerase chain reaction (RT-PCR) and western blot analyses}

GS cells were infected with SGIV at a multiplicity of infection (MOI) of approximately 1 . Total RNA was isolated from mock and virus-infected cells at 4, 6, 8, $12,16,20,24,36$, and $48 \mathrm{~h}$ post-infection (p.i.) using TRIzol reagent (Invitrogen, Carlsbad, CA, USA) according to the manufacturer's instructions. After the RNA was digested with RNase-free DNase, $1 \mu \mathrm{g}$ of RNA from each time point was transcribed using Moloney murine leukemia virus reverse transcriptase (M-MLV RT) and random primers to synthesize the first-strand cDNA. Polymerase Chain Reaction (PCR) was then performed using the primers pair P1/P2 (5'-TGTACCGCTTACTAAATGCC-3' and 5'-GAGTTCCTCCGCTGATGTTA-3', respectively). Detection of $\beta$-actin mRNA using the primer pair P3/P4 (5'-CACTGTGCCCATCTACGAG-3' and 5'-CCATCTCCTGCTCGAAGTC-3', respectively, GenBank: GU145294.1) was used as an internal control. In addition, cycloheximide (CHX) and cytosine $\beta$-D-arabinofuranoside (AraC) were used to classify the temporal expression of SGIV VP39 during infection. Briefly, GS monolayers were pretreated with $50 \mu \mathrm{g} / \mathrm{ml} \mathrm{CHX}$ or $100 \mu \mathrm{g} / \mathrm{ml} \mathrm{AraC} \mathrm{for} 1 \mathrm{~h}$ before and throughout the SGIV infection. CHX- or 
AraC-pretreated cells were mock-infected or infected with SGIV at an MOI of approximately 1, and then harvested at 6 and 48 h p.i., respectively. Total RNA was isolated, and VP39 transcription was analyzed by RT-PCR. The $\beta$-actin gene was used as a control.

To examine the protein expression pattern, western blotting was performed on protein extracts from samples collected at the same time points as described above. Equivalent amounts of cell extracts were electrophoresed on $12 \%$ sodium dodecyl sulfate-polyacrylamide gel electrophoresis (SDS-PAGE) and subsequently transferred to a polyvinylidene fluoride (PVDF) membrane (EMD Millipore, Billerica, MA, USA). Mouse anti-VP39 serum was used as the primary antibody at a dilution of $1: 3,000$, and the secondary antibody was horseradish peroxidase-conjugated goat anti-mouse IgG (Sigma-Aldrich) at a dilution of 1:3,000. Simultaneous internal controls were performed by detecting the $\beta$-actin protein with an anti- $\beta$-actin antibody (Boster Biologics, Pleasanton, CA, USA; 1:3,000).

\section{Indirect immunofluorescence assay}

The subcellular localization of SGIV VP39 was determined by immunofluorescence microscopy. GS cells, grown on cover slips in six-well plates, were infected with SGIV at an MOI of approximately 2. Mock-infected cells were used as a control. At $24 \mathrm{~h}$ p.i., the cells were fixed with $4 \%$ formaldehyde at $4{ }^{\circ} \mathrm{C}$ for 1 $\mathrm{h}$ and permeabilized with $0.2 \%$ Triton $\mathrm{X}-100$ in phosphate-buffered saline (PBS). After blocking with $2 \%$ bovine serum albumen (BSA), the cover slips were incubated 
with mouse anti-VP39 serum at a dilution of 1:75 for $2 \mathrm{~h}$ at room temperature. The cover slips were then incubated with fluorescein isothiocyanate (FITC) labeled goat anti-mouse IgG polyclonal antibody (Thermo Fisher Scientific, Waltham, MA, USA) at a dilution of 1:75 for $2 \mathrm{~h}$ at room temperature, and then stained with $1 \mu \mathrm{g} / \mathrm{ml}$ 4',6'-diamidino-2'-phenylindole (DAPI, Sigma-Aldrich) for $10 \mathrm{~min}$ at room temperature. It was necessary to wash the cover slips three times with PBS between each step. Simultaneous controls were performed by detecting SGIV VP72 (the MCP) with mouse anti-VP72 serum. The samples were examined by fluorescence microscopy (Leica, Wetzlar, Germany).

\section{Virus purification and envelope extraction}

SGIV purification was performed as described previously by Qin et al. (2001, 2003), with modifications. Briefly, virus was inoculated onto confluent monolayers of GS cells at an MOI of 1 . When an advanced cytopathic effect (CPE) was observed, the cell cultures, including medium containing SGIV, were harvested and subjected to three cycles of rapid freezing/thawing and ultrasonication. The suspension containing the lysate, virus, and cellular debris was then centrifuged at $12,000 \times g$ for $30 \mathrm{~min}$ at $4^{\circ} \mathrm{C}$. The supernatant was centrifuged at $210,000 \times g$ for $2 \mathrm{~h}$ at $4^{\circ} \mathrm{C}$. The pellet was resuspended in PBS, and overlaid onto $20-60 \%$ (w/v) sucrose gradients and centrifuged at $210,000 \times g$ for $1 \mathrm{~h}$ at $4^{\circ} \mathrm{C}$. The virus band was collected and diluted with PBS. The virion pellets were finally collected after $1 \mathrm{~h}$ of centrifugation at $100,000 \times g$ at $4^{\circ} \mathrm{C}$ and suspended in PBS, and then stored at $-80^{\circ} \mathrm{C}$ until used. 
Envelope proteins were extracted according to the methods of Zhao et al. (2008). Briefly, purified SGIV particles were treated with an equal volume of $1 \%$ Triton $\mathrm{X}-100(150 \mathrm{mM} \mathrm{NaCl}, 50 \mathrm{mM}$ Tris, $\mathrm{pH} 7.5)$ for $30 \mathrm{~min}$ at room temperature, and centrifuged at $20,000 \times g$ for $30 \mathrm{~min}$ at $4^{\circ} \mathrm{C}$. The supernatant was collected as the envelope fraction, and the pellet was treated with $1 \%$ Triton $\mathrm{X}-100$ for 30 min and centrifuged again to further remove the viral envelope proteins, and then the resulting pellet was collected as the non-envelope fraction.

\section{Analysis of VP39 by matrix-assisted laser desorption/ionization-time of flight tandem mass spectrometry}

The extracted envelope proteins of SGIV were separated by SDS-PAGE and detected by western blotting using the VP39 antibody prepared above. The band corresponding to the VP39 protein was excised and submitted to in-gel tryptic digestion and matrix-assisted laser desorption/ionization-time of flight tandem mass spectrometry (MALDI-TOF/TOF MS/MS) analysis as described by Song et al. (2006). Identification of peptides or proteins were performed using GPS Explorer ${ }^{\mathrm{TM}}$ software version 3.0 (Applied Biosystems, Waltham, MA, USA) employing the MASCOT search engine (version 2.0; Matrix Science, London, UK). The database of the SGIV genome, as well as the International Protein Index (IPI) human database version 3.07 (www.ebi.ac.uk/IPI/IPIhelp.html), were searched. Only proteins having at least one top ranked MS/MS match with an expected value $<0.05$ were accepted as positive identifications. MS/MS spectra were further validated manually. 


\section{Immunogold electron microscopy}

Purified SGIV virus particles were adsorbed onto Formvar-coated, carbonstabilized 200-mesh nickel grids (Ted Pella, Inc, CA, USA) for $1 \mathrm{~h}$ at room temperature. After washing with PBS, the grids were blocked with 3\% BSA for $1 \mathrm{~h}$ and then rinsed with PBS, followed by incubation with mouse anti-VP39 serum as the primary antibody $(1: 100$, diluted in $3 \% \mathrm{BSA})$ for $2 \mathrm{~h}$ at $37^{\circ} \mathrm{C}$. After washing five times with PBS, 10 nm gold-labeled anti-mouse goat IgG (Sigma-Aldrich) was added to the grids as the secondary antibody and incubated for $1 \mathrm{~h}$ at $25^{\circ} \mathrm{C}$. Grids were washed three more times with PBS and stained with $2 \%$ phosphotungstic acid (pH 7.0) for 1 min. Specimens were examined under a transmission electron microscope (JEM-100CX II, JEOL, Tokyo, Japan). As a control experiment, pre-immune serum and mouse anti-SGIV VP72 serum were used in the same way.

\section{Antibody neutralization assay}

The neutralization titer of the mouse anti-VP39 polyclonal antibody was evaluated by a micro neutralization test as described by Zhang et al. (2010). GS cells were cultured in a 96-well cell culture plate. Inactivated mouse anti-rVP39 serum was serially diluted from $1: 1$ to $1: 128$.

The virus was diluted from the virus stock suspension (tissue culture infective dose $\left.\left(\mathrm{TCID}_{50}\right)=10^{6.3}\right)$. Two-fold dilutions of anti-rVP39 serum and the appropriate normal serum controls were made in Leibovitz's L-15 medium (to which an equal 
volume of a constant virus dilution (100 $\mathrm{TCID}_{50}$ per $\left.50 \mu \mathrm{L}\right)$ was added) and incubated in a 96-well cell culture plate at room temperature $\left(25^{\circ} \mathrm{C}\right)$ for $1 \mathrm{~h}$. Each serum dilution was repeated four times. When the GS cells formed a monolayer, $50 \mu \mathrm{l}$ of the incubated antiserum-virus mixture was inoculated onto the cells. After a 1-h adsorption period at $25^{\circ} \mathrm{C}$, the cells were overlaid with modified Leibovitz's L-15 medium. Meanwhile, the following controls were established for the neutralization test. 1) Cell control: normal cells do not exhibit the CPE. 2) Positive serum (immune serum) and negative serum (pre-immune) controls: cells incubated with a high concentration of positive serum do not exhibit the CPE, while cells incubated with negative serum do exhibit the CPE. 3) Virus regression experiment: cell cultures were inoculated with $100,10,1$, or $0.1 \mathrm{TCID}_{50}$ of the virus in the absence of positive serum. Each virus dilution was repeated four times. A $\mathrm{TCID}_{50}$ of 0.1 should not cause the CPE, while a $\mathrm{TCID}_{50}$ of 100 must cause the CPE, otherwise, the test cannot be established. The $50 \%$ serum neutralized dose was calculated by the Reed-Muench method (Reed and Muench 1938).

\section{Results}

\section{Sequence analysis of SGIV VP39}

The GenBank annotation of SGIV ORF39L (YP_164134.1) revealed a previously uncharacterized viral VP39 homolog. The SGIV VP39 gene is 3153 bp long, and it encodes a putative protein of 1051 amino acids, with a predicted molecular mass of $118.2 \mathrm{kDa}$. ScanProsite showed that VP39 contained virus-specific 
two-cysteine adaptor domains, followed by a serine/threonine protein kinase catalytic domain. In vitro studies indicated that purified, recombinant carboxyl-terminally truncated SGIV ORF039L was able to phosphorylate recombinant SGIV ORF075R (Wang et al. 2008). Moreover, VP39 was predicted to contain a transmembrane domain (amino acids 785-808, GASALAQVLLGLAALQRNLGMVHY), two NLSs (amino acids 365-394, TYNKLMRECSDDTSTDSDDTSEPTDRRRRR, and amino acids 694-723, TQDKRRYRPTLVWDQWVGNSEPMESKINRL), an NES (amino acids 791-798, QVLLGLAA), and an arginyl-glycyl-aspartic acid (RGD) motif (amino acids 963-965, RGD) (Fig. 1A).

To better understand the evolutionary history of SGIV VP39, its deduced amino acid sequence was compared to those of grouper iridovirus (GIV), tiger frog virus (TFV), epizootic hematopoietic necrosis virus (EHNV), Chinese giant salamander iridovirus (CGSIV), soft-shelled turtle iridovirus (STIV), frog virus 3 (FV3), Ambystoma tigrinum virus (ATV), infectious spleen and kidney necrosis virus (ISKNV), red seabream iridovirus (RSIV), rock bream iridovirus (RBIV), turbot reddish body iridovirus (TRBIV), orange-spotted grouper iridovirus (OSGIV), lymphocystis disease virus 1 (LCDV-1), lymphocystis disease virus - Chinese isolate (LCDV-C), invertebrate iridescent virus 3 (IIV-3), and invertebrate iridescent virus 6 (IIV-6). A NJ phylogenetic tree was constructed with the amino acid sequences of all 17 homologs of VP39 and SGIV VP39. As shown in Fig.1B, VP39 homologs could be found only in iridoviruses, and the phylogenetic analyses of VP39 homologs revealed low sequence identities among the iridoviruses. VP39 homolog sequence 
identities among members of the iridoviruses differed greatly, and SGIV was most closely related to GIV, as they are likely isolates of the same viral species.

\section{Transcriptional analysis of SGIV VP39 in SGIV-infected GS cells}

The temporal expression pattern of SGIV VP39 in GS cells during viral infection was characterized at both the RNA and protein levels by RT-PCR and western blot analyses, respectively. SGIV VP39 transcription was first detected at 8 h p.i. (Fig. 2A), and translation was first detected at $12 \mathrm{~h}$ p.i. (Fig. 2B). Both the transcription and translation signal intensities increased during the viral infection.

To examine the temporal expression of SGIV VP39 during infection, total RNA was extracted from protein synthesis inhibitor (CHX)- and DNA synthesis inhibitor (AraC)-treated GS cells after SGIV infection. As shown by RT-PCR (Fig. 2C), VP39 expression was inhibited in the presence of $\mathrm{CHX}$ or $\mathrm{AraC}$, but it was expressed in the sample infected with SGIV at $48 \mathrm{~h}$ p.i., thus indicating that the SGIV-VP39 RNA might be a late viral transcript.

\section{Indirect immunofluorescence assay}

An indirect immunofluorescence assay was performed to identify the expression patterns and subcellular location of the SGIV VP39. The nucleic acids of GS cells and viruses within assembly sites were stained blue with DAPI, while the viral protein VP39 was indicated by green fluorescence. As shown in Fig. 3, at $12 \mathrm{~h} \mathrm{p.i.,} \mathrm{the} \mathrm{green}$ fluorescence signal was distributed in both the cytoplasm and the nucleus of 
virus-infected GS cells, suggesting that VP39 diffused into the cytoplasm and nucleus. Then, at $20 \mathrm{~h}$ p.i., the green fluorescence signal began to aggregate into cytoplasmic virus assembly sites (VASs) (indicated by arrows). Until $24 \mathrm{~h}$ p.i., almost all the fluorescence signal aggregated into the VASs. As the infection time increased, the fluorescence density increased (indicated by arrows), suggesting that VP39 might participate in virus assembly. At this moment, the number of stained cells increased progressively as the CPE developed. No green fluorescence was observed in the mock-infected cells.

Early viral gene expression takes place in the nucleus and is catalyzed by host RNA polymerase II. One or more virion-associated proteins act as trans-activators and redirect host RNA polymerase II to synthesize immediate early (IE) and delayed early (DE) viral mRNAs using the methylated viral genome as a template. Gene products encoded by IE and DE viral transcripts include both regulatory and catalytic proteins. One of these gene products, the viral DNA polymerase, catalyzes the first stage of viral DNA synthesis (King et al. 2012). Unit-length viral genomes are synthesized within the nucleus using a virus-encoded DNA polymerase, and they are subsequently transported to the cytoplasm where virion formation takes place in electron-lucent, morphologically distinct VASs (Chinchar et al. 2011). Replication and assembly of iridoviruses often take place in these specific intracellular compartment, where viral components are concentrated (Netherton et al. 2007; Novoa et al. 2005). Genomic DNA, structural proteins, and non-structural proteins contribute to the assembly of the virus, as do different types of membranous structures. The host membranes, perhaps 
derived from the ER, serve as a scaffold to which capsid and shell proteins (a matrix-like domain placed between the DNA-containing nucleoid and the inner envelope) bind. As progressively larger amounts of viral proteins bind the membrane scaffold, the icosahedral vertices are formed (Andres et al. 2002; Suarez et al. 2010).

\section{Identification of VP39 as an envelope protein by Western blot and MS analyses}

Proteins of the SGIV-infected cells, including virions, nucleocapsids, and the envelope fractions, were separated by $12 \%$ SDS-PAGE. Western blot results showed that the polyclonal mouse anti-rVP39 antiserum reacted strongly with an approximately $120 \mathrm{kDa}$ SGIV envelope protein (Fig. 4A), thereby confirming that VP39 is a viral envelope protein.

The results of the western blot analysis showed that VP39 was associated with a single distinct protein band from the viral envelope. The band corresponding to the approximately $120 \mathrm{kDa}$ protein was excised from the gel and subjected to MALDI TOF/TOF MS/MS analyses. Fourteen peptide masses were found to match the predicted peptide masses of VP39 within $100 \mathrm{mg} / \mathrm{l}$, covering $15 \%$ of its amino acid sequence (Fig. 4B). The measured and calculated masses of the tryptic peptides of the MS/MS spectra are shown in Fig. 4C.

Searching the SGIV open reading frame (ORF) database with the tryptic peptide masses showed that one of the proteins was encoded by ORF039L. This means that the resulting amino acid sequences matched that of VP39. 


\section{Immunogold electron microscopy}

The location of the viral protein VP39 on SGIV virions was determined using immunogold electron microscopy. Purified virions showed a well-defined hexagonal outline (Fig. 5A). No gold particles were found on the envelopes of virions when using pre-immune serum as the primary antibody (Fig. 5B). A high density of gold particles was observed on the envelope of the virions when using mouse anti-SGIV VP39 serum as the primary antibody (Fig. 5C), but very few gold particles were bound to the envelope of the virions when using mouse anti-SGIV MCP serum as the primary antibody (Fig. 5D). After treatment with Triton X-100 (1\%) for $30 \mathrm{~min}$, the viral envelope was almost completely removed, and the viral capsid appeared as a bright ring around the electron-dense core (Fig. 5E) (indicated by arrows). The envelope of the virions was degraded, and very few gold particles were found on the viral capsid when using the pre-immune serum (Fig. 5F) or mouse anti-SGIV VP39 serum as the primary antibody (Fig. 5G). After treatment with 1\% Triton X-100 for 30 min, the viral capsid was visible, and the capsid was labeled with a high density of gold particles when using mouse anti-SGIV MCP serum as the primary antibody (Fig. $5 \mathrm{H})$.

\section{Antibody neutralization assay}

To investigate whether SGIV VP39 is involved in virus infection, neutralization assays using antibodies against the VP39 protein were performed on SGIV-infected GS cells. Neutralization was calculated by determining the infectivity of SGIV. 
Infectivity was calculated as the ratio of plaque-forming units (PFUs) for each virus preparation that was incubated with the corresponding dilution of antibody relative to the number of PFUs obtained by incubating with media alone. From this, the 50\% serum neutralized titer was calculated. As shown in Fig. 6, the neutralization titer of the mouse anti-SGIV VP39 polyclonal antibody was 1:16.

Antisera raised against individual viral envelope proteins have been used successfully in neutralization assays to identify envelope proteins involved in viral infections (Schofield et al. 2000; Wu et al. 2005). In this study, the antibody neutralization assays indicated that the mouse anti-VP39 serum neutralizes SGIV. Therefore, SGIV VP39 is likely to be involved in systemic SGIV infections.

\section{Discussion}

SGIV ORF39L had been predicted to encode a viral structural protein (Song et al. 2004). ORF39L was identified as a core gene of the family Iridoviridae, and it was predicted to be a serine/threonine protein kinase (Eaton et al. 2007). The influence of serine/threonine protein kinases on viral infection in cell cultures varies, and they usually play important roles in virulence. For example, the UL13 and US3 kinases of herpes simplex virus regulate the expression of cellular and viral genes, mediate the nuclear egress of viral nucleocapsids, and are required for evasion of the host immune response (Cano-Monreal et al. 2009; Eaton et al. 2014). Another SGIV serine/threonine protein kinases, ORF018R, is involved in serine/threonine phosphorylation in SGIV-infected late-stage cells, and it plays an important role in the 
expression of viral late genes and virion assembly (Wang et al. 2008). In addition, bioinformatics analysis also indicated that VP39 has two cysteine-rich adaptor domains, which were also found in vaccinia virus membrane protein A16. Cysteine-rich motifs in viral membrane proteins were confirmed to be required for viral entry and cell-cell fusion (Ojeda et al. 2006). Serine/threonine protein kinases that contain cysteine-rich repeats are present in many bacterial species, where they control various physiological and virulence processes by enabling microbial adaptation to specific environmental signals (Jang et al. 2010). All these features co-exist in VP39, suggesting that VP39 might play important roles during SGIV infection. However, the function of serine/threonine protein kinases in iridoviruses is largely unknown. Thus, future work will be directed toward elucidating the functions of SGIV VP39 in viral infection.

The family Iridoviridae currently contains five genera, including the Iridovirus and Chloriridovirus genera that are associated with insects, the Lymphocystivirus and Megalocytivirus genera, which infect fish species, and the genus Ranavirus, whose members have been associated with mortality in amphibians, fish, and reptiles. Phylogenetic analysis based on SGIV VP39 shows a clear division between the genera within the family Iridoviridae, with SGIV being a member of the genus Ranavirus in the family Iridoviridae. In addition, SGIV is more closely related to GIV, and the grouper iridoviruses SGIV and GIV are clearly more divergent from the ATV/EHNV and STIV/TFV and FV-3/CGSIV ranaviruses. This supports previous suggestions that ranaviruses are currently subdivided into amphibian-like ranaviruses 
and GIV-like ranaviruses, which have been found only in fish thus far (Jancovich et al. 2010). SGIV is more distantly related to LCDV-1 and LVDC-C, IIV-3, IIV-6, and ISKNV, RBIV, RSIV, TRBIV, and OSGIV, which are members of the Lymphocystivirus, Iridovirus, Chloriridovirus, and Megalocytivirus genera, respectively. Notably, SGIV was more closely related to IIV-3 and IIV-6 (which belong to the Iridovirus and Chloriridovirus genera, respectively, and are associated with insects) than to ISKNV, RBIV, RSIV, TRBIV, and OSGIV (which belong to the Megalocytivirus genus and infect fish species). Studies of the conserved domains of SGIV VP39 and other members of the iridovirus family demonstrated that ISKNV, RBIV, RSIV, TRBIV, and OSGIV carry only a truncated version of the VP39 gene that lacks the carboxyl-terminal serine/threonine protein kinase motif. Similar results were obtained following a phylogenetic analysis of ranaviruses that was based on vIF-2 $\alpha$ (Anke et al. 2015). Sequencing demonstrated that several ranaviruses (FV3, STIV) carry only a truncated version of the vIF- $2 \alpha$ gene that lacks the amino-terminal binding domain for the protein kinase $\mathrm{R}$ and the central helical domains. All ranaviruses with truncated vIF- $2 \alpha$ genes branched very closely to one another in the FV3-like group, which supports previous findings on sequence gain and loss during ranaviral evolution (Abrams et al. 2013; Anke et al. 2015). Thus, it is reasonable to infer that, based on the phylogenetic analysis, SGIV is more distantly related to an ISKNV-like megalocytivirus, which may be the result of an ISKNV-like megalocytivirus gaining and losing VP39 orthologs during its evolution. A number of environmental and host factors, as well as different virus strains and specific 
combinations of host and virus genotypes, seem to impact the development of evolution of the family Iridoviridae.

Iridovirus genes are expressed in three main temporal kinetic expression classes: IE, early (E), and late (L) (Williams et al. 2007). IE, E, and L genes can be defined experimentally using the protein synthesis inhibitor CHX and the DNA replication inhibitor AraC (Nalcacioglu et al. 2003, 2007). In general, IE genes are transcribed immediately after infection and, despite SGIV being a cytoplasmic virus, are transcribed, via host RNA polymerase II, in the nucleus. Thus, the transcripts cannot be inhibited in the presence of protein synthesis inhibitors. E gene transcription is mediated by putative virus-encoded (for E mRNA) transcriptional trans-activators. E genes are expressed later via the action of IE products, and they include enzymes involved in viral DNA replication and nucleic acid metabolism. Hence, E gene transcription can be blocked by protein synthesis inhibitors, but not by viral DNA polymerase inhibitors (Chinchar et al. 2011; Zhao et al. 2007). L genes are expressed after the onset of viral DNA replication, and they encode some metabolic enzymes and structural proteins of viral particles (Chambers et al. 1999); L gene transcription requires de novo protein synthesis and viral DNA replication. Expression of the VP39 gene was inhibited in the presence of $\mathrm{CHX}$ and $\mathrm{AraC}$, and it was only detected in the sample infected with SGIV at $48 \mathrm{~h}$ p.i. Notably, the data based on the temporal expression pattern and the drug inhibition assay revealed that SGIV VP39 belongs to the L class of genes during in vitro infection, as shown by DNA microarray analyses (Chen et al. 2008; Teng et al. 2008). 
SGIV VP39 was predicted to be a serine/threonine protein kinase (Eaton et al. 2007), and it is able to phosphorylate recombinant SGIV ORF075R (Wang et al. 2008). Viral serine/threonine protein kinases may translocate predominantly into the nucleus (Chang et al. 2012). The NLS_Mapper Server and NetNES Server predicted that VP39 contained NLSs and NESs. Consequently it would be expected for the green fluorescence to be distributed. The intracellular distribution and dynamic changes of SGIV VP39 in infected cells revealed that VP39 ultimately localizes to the VAS. The major structural proteins are expected to localize to the VAS, as are immature virions and intracellular mature virions (Alzhanova et al. 2006; VanSlyke et al. 1994). Thus, it is reasonable to infer that the major viral structural protein VP39 is involved in SGIV replication and assembly.

Structural proteins of iridoviruses may be envelope proteins, capsid proteins, inner membrane proteins, or nucleoproteins. Envelope proteins usually play vital roles, such as binding to receptors or entering into host cells via membrane fusion and translocation, in the viral lifecycle (Yamauchi et al. 2013). VP39 was predicted to contain a transmembrane domain (from amino acids 785-808), which suggested that VP39 was an envelope protein. Moreover, VP39 has an RGD peptide, which is the minimal protein motif involved in cell attachment. Viral RGD-containing proteins have been shown to be involved in viral infections and virus-host interactions by interacting with host cell surface receptors (Wang et al. 2003; Williams et al. 2004). Western blot and MALDI TOF/TOF MS/MS analyses and immunogold electron microscopy further determined that VP39 is a viral envelope protein. 
In conclusion, we have characterized the VP39-encoding gene of the family Iridoviridae by bioinformatic, phylogenetic, transcription, and translation analyses. VP39 was identified in the cytoplasmic VASs of infected cells, and it was shown to be a viral envelope protein. Neutralization assays further revealed that anti-SGIV VP39 serum could block SGIV infection in GS cells. We believe that these results will aid our understanding of the envelope structure of iridoviruses, as well as the molecular mechanisms of iridovirus infection. Future experiments should be performed to further uncover the role of VP39 in SGIV systemic infections.

\section{Acknowledgments}

This work was supported by grants from the National Basic Research Program of China (973) (grant numbers 2012CB114402 and 2012CB114406), the National

Natural Science Foundation of China (grant numbers 31172445, 30930070, and 31172437), the Knowledge Innovation Program of the Chinese Academy of Sciences (grant number KSCX2-EW-G-12B), and the National High-Tech Research and Development Program (863) (grant number SS2014AA091607).

\section{References}

Abrams, A.J., Cannatella, D.C., Hillis, D.M., and Sawyer, S.L. 2013. Recent host-shifts in ranaviruses: signatures of positive selection in the viral genome. J.Gen.Virol. 94: 2082-2093. doi: 10.1099/vir.0.052837-0. PMID: 23784445. 
Alzhanova, D., and Hruby, D.E. 2006. A trans-Golgi network resident protein, golgin-97, accumulates in viral factories and incorporates into virions during poxvirusinfection. J.Virol. 80:11520-11527. doi:10.1128/JVI.00287-06. PMID:16987983.

Andres, G.., Alejo, A., Salas, J., and Salas, M.L. 2002. African swine fever virus polyproteins pp220 and pp62 assemble into the core shell. J.Virol. 76(24): 12473-12482. doi: 10.1128/JVI.76.24.12473-12482. PMID: 12438573

Anke, C. Stöhr., Alberto, López-Bueno., Silvia, Blahak., Maria, F., et al. 2015. Phylogeny and Differentiation of Reptilian and Amphibian Ranaviruses Detected in Europe. PLOS. ONE. doi:10.1371/journal.pone.0118633

Braunwald, J., Nonnenmacher, H., and Tripier-Darcy, F. 1985. Ultrastructural and biochemical study of frog virus 3 uptake by BHK-21 cells. J. Gen. Virol. 66(Pt2):283-293. doi:10.1099/0022-1317-66-2-283. PMID:3918142.

Cano-Monreal, G.L., Wylie, K.M., Cao, F., Tavis, J.E., and Morrison, L.A. 2009. Herpes simplex virus 2 UL13 protein kinase disrupts nuclear lamins. Virology. 392(1):137-47. doi: 10.1016/j.virol.2009.06.051. PMID: 19640559 
Chambers, J., Angulo, A., Amaratunga, D., Guo, H., Jiang, Y., Wan, J.S., et al. 1999. DNA microarrays of the complex human cytomegalovirus genome: profiling kinetic class with drug sensitivity of viral gene expression. J. Virol. 73:5757-5766. PMID: 10364327.

Chang, C.W., Lee, C.P., Huang, Y.H., Yang, P.W., Wang, J.T., and Chen, M.R. 2012. Epstein-Barr virus protein kinase BGLF4 targets the nucleus through interaction with nucleoporins. J. Virol. 86(15): 8072-85. doi: 10.1128/JVI.01058-12. PMID: 22623767

Chen, L.M., Tran, B.N., Lin, Q.S., Lim, T.K., Wang, F.,and Hew, C.L. 2008 iTRQ analysis of Singapore grouper iridovirus infection in a grouper embryonic cell line. J. Gen. Virol. 89:2869-2876. doi:10.1099/vir.0.2008/003681-0. PMID: 18931085.

Chen, L.M.,Wang, F., Song,W., and Hew, C.L. 2006. Temporal and differential gene expression of Singapore grouper iridovirus. J. Gen. Virol. 87: 2907-2915. doi:10.1099/vir.0.82219-0. PMID: 16963749.

Chinchar, V.G., Yu, K.H., and Jancovich, J.K. 2011. The molecular biology of frog virus 3 and other iridoviruses infecting cold-blooded vertebrates. Viruses. 3:1959-1985. http://dx.doi.org/10.3390/v3101959. PMID: 22069524 
Chinchar, V.G., and Waltzek, T.B. 2014. Ranaviruses: Not Just for Frogs. PloS Pathog. 10(1): e1003850. doi:10.1371/journal.ppat.1003850. PMID: 24453965

Eaton, H.E., Metcalf, J., Penny, E., Tcherepanov, V., Upton, C., and Brunetti, C.R. 2007. Comparative genomic analysis of the family Iridoviridae: re-annotating and defining the core set of iridovirus genes. Virol. J. 4:11-17. doi: 10.1186/1743-422X-4-11. PMID: 17239238.

Eaton, H.E., Saffran, H.A., Wu, F.W., Quach, K., and Smiley, J.R. 2014. Herpes simplex virus protein kinases US3 and UL13 modulate VP11/12 phosphorylation, virion packaging, and phosphatidylinositol 3-kinase/Akt signaling activity. J. Virol. 88(13):7 379-88. doi: 10.1128/JVI.00712-14. PMID: 24741093

Gendrault, J.L.; Steffan, A.M.; Bingen, A.; and Kirn, A. 1981. Penetration and uncoating of frog virus 3 (FV3) in cultured rat Kupffer cells. Virology. 112: 375-384.

Gray, M.J., Miller, D.L., and Hoverman, J.T. 2009. Ecology and pathology of amphibian ranaviruses. Dis. Aquat. Organ. 87:243-266. Doi: 10.3354/dao02138. PMID: 20099417. 
Huang, X.H., Huang, Y.H., Ouyang, Z.L., Xu, L.X., Yan, Y., Cui, H.C., et al. 2011. Singapore grouper iridovirus, a large DNA virus, induces nonapoptotic cell death by a cell type dependent fashion and evokes ERK signaling. Apoptosis. 16:831-845. doi: 10.1007/s10495-011-0616-y. PMID: 21656148.

Jancovich, J.K., Brémont, M., Touchman, J.F., and Jacobs, B.L. 2010. Evidence for multiple recent host species shifts among the ranaviruses (family Iridoviridae). J. Virol. 84: 2636-2647. doi: 10.1128/JVI.01991-09. PMID: 20042506

Jancovich, J.K., Chinchar, V.G., Hyatt, A., Miyazaki, T., and Williams, T. 2012. Family Iridoviridae. In: King AMQ, Adams MJ, Carstens EB, Lefkowitz EJ, editors. Virus taxonomy: classification and nomenclature of viruses. Ninth report of the International Committee on Taxonomy of Viruses. Amsterdam: Elsevier. pp. 193-210.

Jang, J.C., Stella, A., Boudou, F., Levillain, F., Darthuy, E., Vaubourgeix, J.,et al. 2010. Functional characterization of the Mycobacterium tuberculosis serine/threonine kinase PknJ Microbiology. 156:1619-1631. doi: 10.1099/mic.0.038133-0. PMID: 20185505.

King, A.M.Q., Lefkowitz, E., Adams, M.J., Carstens, E.B., Eds. 2012. Virus Taxonomy Classification and Nomenclature of Viruses: 9th Report of the 
International Committee on Taxonomy of Viruses. Elsevier: San Diego, CA, USA.

Lesbarrères, D., Balseiro, A., Brunner, J., Chinchar, V.G., Duffus, A., Kerby, J., et al. 2012. Ranavirus: past, present and future. Biol. Lett. 8:481-493. doi: 10.1098/rsbl.2011.0951. PMID: 22048891.

Monini, M., and Ruggeri, F.M., 2002. Antigenic peptides of the epizootic hematopoietic necrosis virus. Virology. 297: 8-18. PMID: 12083831.

Nalcacioglu, R., Ince, I.A., Vlak, J.M., Demirbag, Z., and Oers, M.M. 2007.The Chilo iridescent virus DNA polymerase promoter contains an essential AAAAT motif. J. Gen. Virol. 88: 2488-2494. doi:10.1099/vir.0.82947-0. PMID: 17698658.

Nalcacioglu, R., Marks, H., Vlak, J.M., Demirbag, Z., and Oers, M.M. 2003. Promoter analysis of the Chilo iridescent virus DNA polymerase and major capsid protein genes. Virology. 317:321-329. PMID: 14698670.

Netherton, C., Moffat, K., Brooks, E., and Wileman, T.A. 2007. guide to viral inclusions, membrane rearrangements, factories, and viroplasm produced during virus replication. Adv. Virus. Res. 70: 101- 182. doi: 10.1016/S0065 -3527(07) 70004-0. PMID: 17765705. 
Novoa, R.R., Calderitam, G., Arranz, R., Fontana, J., Granzow, H., and Risco, C. 2005. Virus factories: associations of cell organelles for viral replication and morphogenesis. Biol.Cell. 97:147-172. doi:10.1042/BC20040058. PMID:15656780.

Ojeda, S., Senkevich, T.G., and Moss, B. 2006. Entry of vaccinia virus and cell-cell fusion require a highly conserved cysteine-rich membrane protein encoded by the A16L gene. J.Virol. 80:51-61. doi:10.1128/JVI.80.1.51-61.2006. PMID: 16352530.

Qin, Q.W., Chang, S.F., Ngoh-Lim, G.H., Gibson-Kueh, S., Shi, C., and Lam, T.J. 2003. Characterization of a novel ranavirus isolated from grouper Epinephelus tauvina. Dis. Aquat. Organ. 53:1-9. doi:10.3354/dao053001. PMID:12608562.

Qin, Q.W., Lam, T.J., Sin, Y.M., Shen, H., Chang, S.F., Ngoh-Lim, G.H. et al. 2001. Electron microscopic observations of a marine fish iridovirus isolated from brown-spotted grouper, Epinephelus tauvina. J. Virol. Methods. 98:17-24. PMID:11543880. 
Qin, Q.W., Shi, C., Gin, K.Y., and Lam, T.J. 2002. Antigenic characterization of a marine fish iridovirus from grouper, Epinephelus spp. J.Virol. Methods. 106: 89-96. PMID: 12367733.

Qin,Q.W., Wu,T.H., Jia,T.L., Hegde,A., and Zhang,R.Q. 2006. Development and characterization of a new tropical marine fish cell line from grouper, Epinephelus coioides susceptible to iridovirus and nodavirus. J. Virol. Methods. 131: 58-64 doi: 10.1016/j.jviromet.2005.07.009. PMID: 16137774.

Reed, L.J., and Muench, H.1938. A simple method of estimating fifty percent endpoints. Am .J. Epidemiol. 27:493-497

Rothermel, B.B., Travis, E.R., Miller, D.L., Hill, R.L., McGuire, J.L., and Yabsley, M.J. 2013. High occupancy of stream salamanders despite high ranavirus prevalence in a southern appalachians watershed. Ecohealth. 10:184-189. doi: 10.1007/s10393-013-0843-5. PMID: 23645459

Schock, D.M., Ruthig, G.R., Collins, J.P., Kutz, S.J., Carrière, S. et al. 2010. Amphibian chytrid fungus and ranaviruses in the Northwest Territories, Canada. Dis. Aquat. Organ. 92:231-240. doi: 10.3354/dao02134. PMID: 21268986

Schofield, D.J., Glamann, J., Emerson, U., and Purchell, R.H. 2000. Identification by 
phage display and characterization of two neutralizing chimpanzee monoclonal antibodies to the hepatitis E virus capsid protein. J. Virol. 74: 5548-5555. PMID: 10823861.

Song, W.J., Lin, Q., Joshi, S.B., Lim, T.K., and Hew, C.L. 2006. Proteomic studies of the Singapore grouper iridovirus. Mol. Cell. Proteomics. 5:256-264. Doi: 10.1074/mcp.M500149-MCP200. PMID:16263702.

Song, W.J., Qin, Q.W., Qiu, J., Huang, C.H., Wang, F., and Hew, C.L. 2004. Functional genomics analysis of Singapore grouper iridovirus: complete sequence determination and proteomic analysis. J. Virol. 78:12576-12590. Doi: 10.1128/JVI.78.22.12576-12590. PMID: 15507645.

Suarez, C., Salas, M.L., and Rodriguez, J.M. 2010. African swine fever virus polyprotein pp62 is essential for viral core development. J. Virol. 84: 176-187. doi: 10.1128/JVI.01858-09. PMID: 19846532

Teng, Y., Hou, Z., Gong, J., Liu, H., Xie, X., Zhang, L. et al. 2008. Whole-genome transcriptional profiles of a novel marine fish iridovirus, Singapore grouper iridovirus (SGIV) in virus-infected grouper spleen cell cultures and in orange-spotted grouper, Epinephulus coioides. Virology. 377:39-48. doi : 10.1016/j.virol.2008.04.011. PMID:18555886. 
VanSlyke, J.K., and Hruby, D.E. 1994. Immunolocalization of vaccinia virus structural proteins during virion formation. Virology. 198: 624-635. doi : 10.1006/viro.1994.1074. PMID:8291244.

Wan, Q.J., Gong, J., Huang, X.H., Huang, Y.H., Zhou, S. et al. 2010. Identification and characterization of a novel capsid protein encoded by Singapore grouper iridovirus ORF038L. Arch. Virol. 155:351-359. doi: 10.1007/s00705-010-0594 -3. PMID:20130938.

Wang, F., Bi, X.Z., Chen, L.M.,and Hew, C.L. 2008. ORF018R, a highly abundant virion protein from Singapore grouper iridovirus, is involved in serine/ threonine phosphorylation and virion assembly. J. Gen. Virol. 89:1169-1178. doi: 10.1099/vir.0.83639-0. PMID: 18420794.

Wang, F.Z., Akula, S.M., Sharma-Walia, N., Zeng, L., and Chandran, B. 2003. Human herpesvirus 8 envelope glycoprotein B mediates cell adhesion via its RGD sequence. J. Virol. 77:3131-3147. PMID: 12584338

Wang, S., Huang, X., Huang ,Y., Hao, X., Xu, H., and Qin, Q. 2014. Entry of a novel marine DNA virus, Singapore grouper iridovirus, into host cells occurs via 
clathrin-mediated endocytosis and macropinocytosis in a $\mathrm{pH}-\mathrm{dependent} \mathrm{manner.}$ J. Virol. 88(22):13047-63. doi:10.1128/JVI.01744-14. PMID: 25165116

Williams, C.H., Kajander, T., Hyypia, T., Jackson, T., Sheppard, D., and Stanway, G. 2004. Integrin alpha v beta 6 is an RGD-dependent receptor for coxsackievirus A9. J. Virol. 78:6967-6973. doi:10.1128/JVI.78.13.6967-6973. PMID: 15194773

Williams, T., Barbosa, S.V., and Chinchar, V.G. 2005. A decade of advances in iridovirus research. Adv.Virus. Res. 65:173-248. doi: 10.1016/S0065- 3527(05) 65006-3. PMID: 16387197.

Whittington, R.J., Becker, J.A., and Dennis, M.M. 2010. Iridovirus infections in finfish critical review with emphasis on ranaviruses. J. Fish. Dis. 33:95-122. doi: 10.1111/j.1365-2761.2009.01110.x. PMID:20050967.

Wu, W.L., Wang, L., and Zhang, X.B. 2005. Identification of white spot syndrome virus (WSSV) envelope proteins involved in shrimp infection. Virology. 332: 578-583. doi:10.1016/j.virol.2004.12.011. PMID:15680422.

Yamauchi, Y., and Helenius, A. 2013. Virus entry at a glance. J. Cell. Sci. 15:126(Pt 6):1289-1295. doi: 10.1242/jcs.119685. PMID:23641066. 
Yan, X., Olson, N. H. ,Van Etten, J. L., Bergoin, M., Rossmann, M. G. et al. 2000. Structure and assembly of large lipid-cintaining dsDNA viruses. Nat. Struct. Bio. 17:101-103. doi: 10.1038/72360 . PMID:10655609.

Zhang, S.H., Xiang, J., Cheng, A.C., Mingshu., Wang, M.S., Li, X. et al. 2010. Production, purification and characterization of polyclonal antibody against the truncated gK of the duck enteritis virus. Virology. J. 7:241. doi: 10.1186/1743422X-7-241. PMID:20846457.

Zhao,Z., Ke, F., Gui, J.F., and Zhang, Q.Y. 2007. Characterization of an early gene encoding for dUTPase in Rana grylio virus. Virus. Res. 123:128-137. doi :10. 1016/j.virusres.2006.08.007. PMID:16989917

Zhao, Z., Ke, F., Huang, Y.H., Zhao, J.G., Gui, J.F., and Zhang, Q.Y. 2008. Identification and characterization of a novel envelope protein in Rana grylio virus. J.Gen.Virol. 89:1866-1872. doi:10.1099/vir.0.2008/000810-0. PMID:18632957. 
Table 1 SGIV VP39 homologs used in this study

\begin{tabular}{|c|c|c|}
\hline Name of virus (Abbreviation) & Viral protein & $\begin{array}{l}\text { NCBI Reference } \\
\text { Sequence }\end{array}$ \\
\hline Singapore grouper iridovirus (SGIV) & ORF039L & YP_164134.1 \\
\hline Grouper iridovirus (GIV) & Unknown protein & AAV91044.1 \\
\hline $\begin{array}{l}\text { Epizootic hematopoietic necrosis } \\
\text { virus }(\mathrm{EHNV})\end{array}$ & $\begin{array}{l}\text { Serine/threonine protein } \\
\text { kinase }\end{array}$ & ACO25279.1 \\
\hline Frog virus 3 (FV3) & $\begin{array}{l}\text { Hypothetical protein } \\
\text { FV3gorf19R }\end{array}$ & YP_031597.1 \\
\hline Tiger frog virus (TFV) & Hypothetical protein & ABB92284.1 \\
\hline Ambystoma tigrinum virus (ATV) & Unknown protein & YP_003855.1 \\
\hline Soft-shelled turtle iridovirus (STIV) & Unknown protein & ACF42240.1 \\
\hline Rock bream iridovirus (RBIV) & ORF053L & AAT71868.1 \\
\hline Red seabream iridovirus (RSIV) & $\begin{array}{l}\text { Hypothetical protein } \\
\text { ORF 106R }\end{array}$ & BAK14231.1 \\
\hline $\begin{array}{l}\text { Turbot reddish body iridovirus } \\
\text { (TRBIV) }\end{array}$ & ORF52L & ADE34397.1 \\
\hline $\begin{array}{l}\text { Infectious spleen and kidney necrosis } \\
\text { virus (ISKNV) }\end{array}$ & ORF055L & NP_612277.1 \\
\hline $\begin{array}{l}\text { Lymphocystis disease virus - Chinese } \\
\text { isolate (LCDV-C) }\end{array}$ & $\begin{array}{l}\text { Serine/threonine protein } \\
\text { kinase }\end{array}$ & YP_073522.1 \\
\hline $\begin{array}{l}\text { Lymphocystis disease virus } 1 \text { (LCDV } \\
\text {-1) }\end{array}$ & $\begin{array}{l}\text { Hypothetical protein } \\
\text { LCDV1gp005 }\end{array}$ & NP_078619.1 \\
\hline Invertebrate iridescent virus 3 (IIV-3) & $\begin{array}{l}\text { Hypothetical protein } \\
\text { MIV010L }\end{array}$ & YP_654582.1 \\
\hline Invertebrate iridescent virus 6 (IIV-6) & ORF380R & NP_149843.1 \\
\hline $\begin{array}{l}\text { Chinese giant salamander iridovirus } \\
\text { (CGSIV) }\end{array}$ & $\begin{array}{l}\text { Serine/threonine-protein } \\
\text { kinase }\end{array}$ & AHA- 80941.1 \\
\hline $\begin{array}{l}\text { Orange-spotted grouper iridovirus } \\
\text { (OSGIV) }\end{array}$ & ORF55L & AAX82364.1 \\
\hline
\end{tabular}

\section{Figures and legends}

Fig. 1 Characteristics of SGIV VP39. (A) Amino acid alignment of SGIV VP39. The predicted nuclear localization signals are underlined, and the nuclear export signal is boxed with a rectangle. The predicted transmembrane (TM) domain is indicated with a curved line. The predicted RGD motif is indicated with a double line. (B) 
Phylogenetic analysis of VP39 from 17 iridovirus species. The phylogenetic analysis was performed by the neighbor-joining method using MEGA 5.1 software packages, with 1000 bootstrap replicates. The trees yielded identical topologies for each protein. Branch lengths were proportional to the numbers of amino acid substitutions. Genera are indicated by brackets labeled as follows: R, Ranavirus; M, Megalocytivirus; L, Lymphocystivirus; C, Chloriridovirus; I, Iridovirus.

Fig. 2 The temporal expression pattern of SGIV VP39 in grouper spleen cells during virus infection. (A) Reverse transcription-polymerase chain reaction analysis of SGIV VP39 transcription. Transcription of SGIV VP39 was first detected at 8 h p.i. (B) Western blot analysis of SGIV VP39. Expression of SGIV VP39 was detected as early as $12 \mathrm{~h}$ p.i. Both transcription and expression signal intensities increased during viral infection. (C) VP39 was inhibited in the presence of cycloheximide (CHX) and $\beta$-D-arabinofuranoside (AraC), and it was only expressed in SGIV-infected cells at 48 h p.i.

Fig. 3 Subcellular localization of SGIV VP39 during viral infection as detected by an immunofluorescence assay. The fluorescence signal in the fluorescein isothiocyanate (FITC) channel indicates the expression of SGIV VP39. The cell nucleus and viral assembly sites (VASs) were stained by 4',6'-diamidino-2'-phenylindole (DAPI). SGIV VP39 accumulated in the cytoplasm and nucleus early in the infection, and it localized to VASs at the late stage of infection. The VASs are indicated by arrows. 
Fig. 4 Identification of SGIV VP39 by western blot and mass spectrometry (MS) analyses. (A) Western blot analysis of SGIV VP39. M, protein marker (116 kDa); VI, viral-infected cells; V, SGIV virion; E, envelope protein fraction of SGIV; and N, nucleocapsids of SGIV. Anti-VP39 serum was used as the primary antibody in the western blot analysis. (B) The peptides matched the protein sequence of VP39. Matched peptides by time of flight (TOF) 1 are shown in bold red, as are peptides confirmed by TOF 2. The transmembrane domain from amino acids 785 to 808 is double underlined in black. (C) MS spectra of the peptides identified by TOF 2. a. Spectrum of peptide 1: YTTVYGHSELTMAAR; b. Spectrum of peptide 2: WADNWLVSDHVVGR; c. Spectrum of peptide 3: GSFGAVHIVQLR; d. Spectrum of peptide 4: TLPGGFWAIR; e. Spectrum of peptide 5: QSVNFSPYHGIR; f. Spectrum of peptide 6: FPAWEWR. The peptides are modified with carboxymethyl groups.

Fig. 5 Immunoelectron microscopy. (A) The purified virions showed a well-defined hexagonal outline. (B) Blank control; no gold particles were found on the virion envelope using pre-immune serum as the primary antibody. (C) Colloidal gold particles labeled the envelope of virions using anti-SGIV VP39 antibody as the primary antibody. (D) Negative control; no colloidal gold particles were found on the envelope of virions using anti-SGIV major capsid protein (MCP) antibody as the primary antibody. (E) After treatment with Triton X-100 (1\%) for $30 \mathrm{~min}$, the viral envelope was almost completely removed, and the viral capsid appeared as a bright 
ring around an electron-dense core (indicated by arrows). (F) Blank control; the envelope of the virions was degraded, and very few gold particles were found on the viral capsid when using pre-immune serum as the primary antibody. (G) The envelope of the virions was degraded, and very few gold particles were found on the viral capsid when using mouse anti-SGIV VP39 serum as the primary antibody. $(\mathrm{H})$ Negative control; after treatment with $1 \%$ Triton X-100 for 30 min, the viral capsid was visible and a high density of gold particles was observed on the removed envelope when using mouse anti-SGIV MCP serum as the primary antibody. The scale bars represent $100 \mathrm{~nm}$.

Fig. 6 Neutralization of SGIV infection in vitro by mouse anti-SGIV VP39 antibody. Viruses were mixed with serial dilutions of the corresponding antibody, incubated at room temperature $\left(25^{\circ} \mathrm{C}\right)$ for $1 \mathrm{~h}$, inoculated onto grouper spleen cells grown in 96-well plates, and at 3 days post-infection, the cytopathic effect was detected under a light microscope. Infectivity was calculated as the ratio of the number of plaque-forming units (PFUs) obtained for each virus incubated with the corresponding dilution of antibody relative to the number of PFUs obtained by incubating the respective virus with media alone. Error bars represent standard errors of the means. Dashed lines indicate the serum dilutions at which a 50\% PFU reduction was reached. 
A
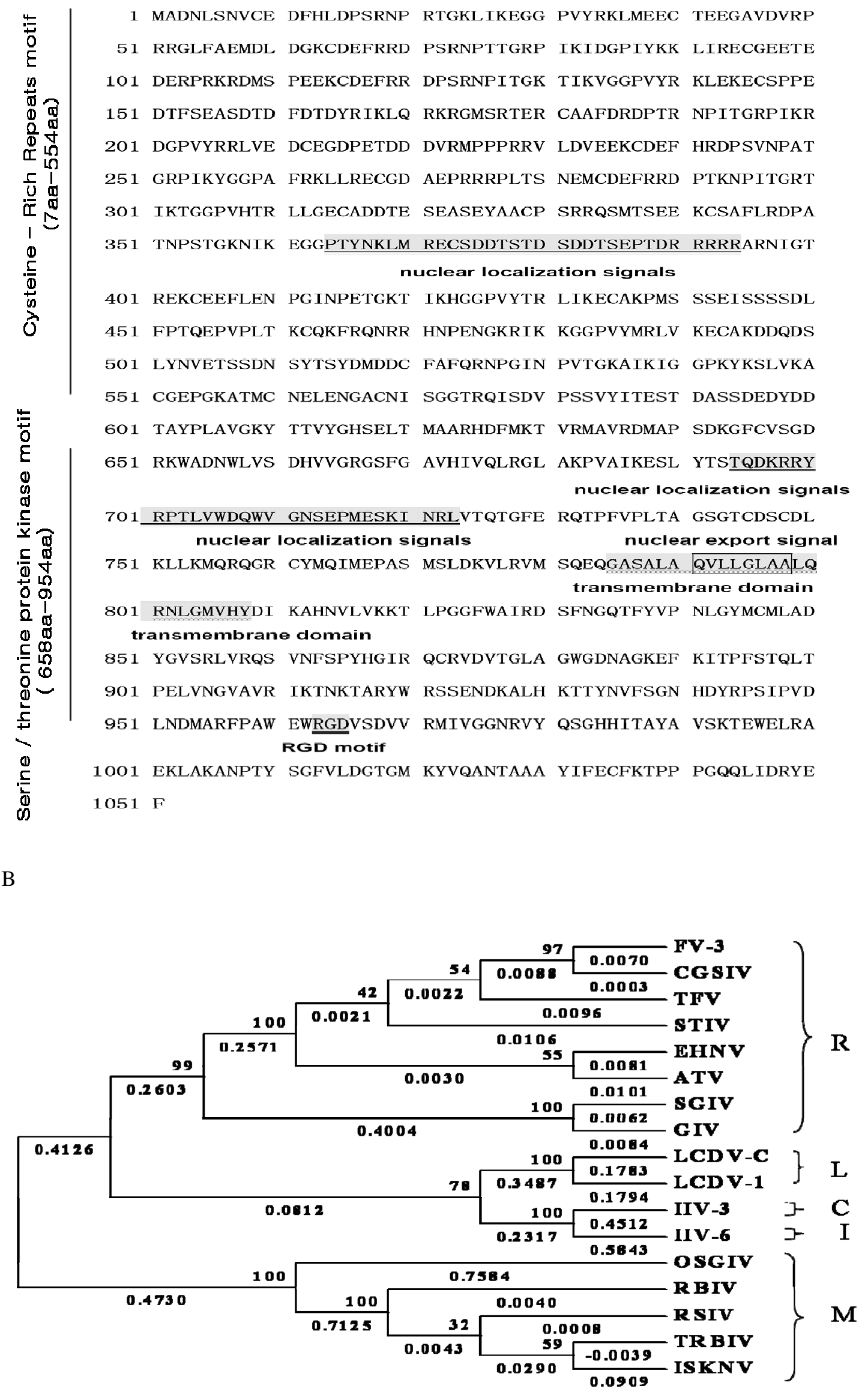
A

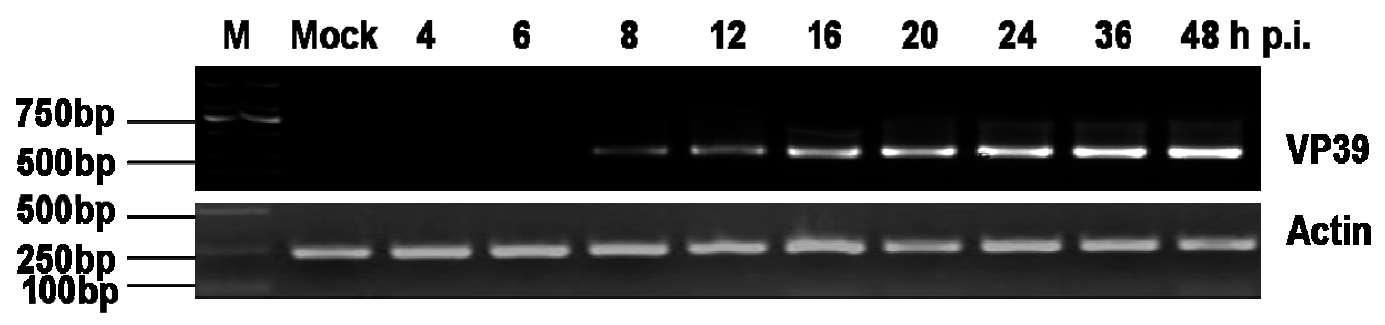

B

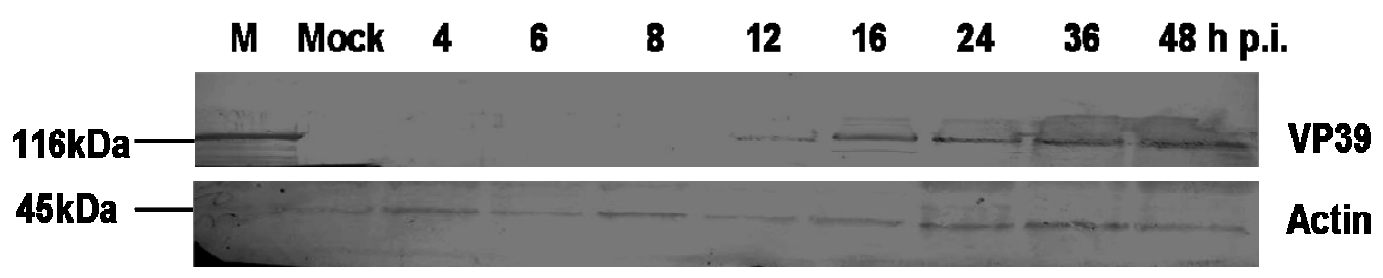

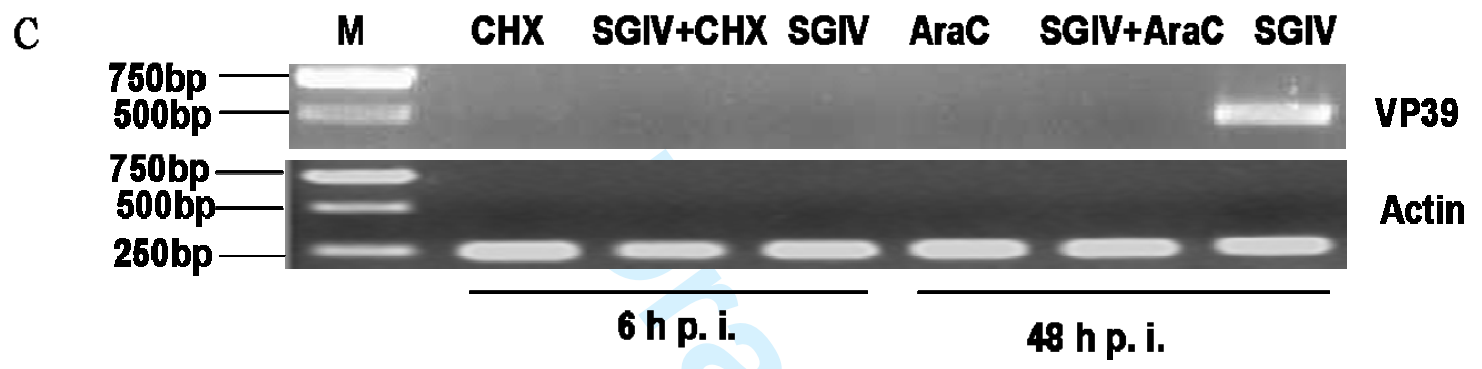




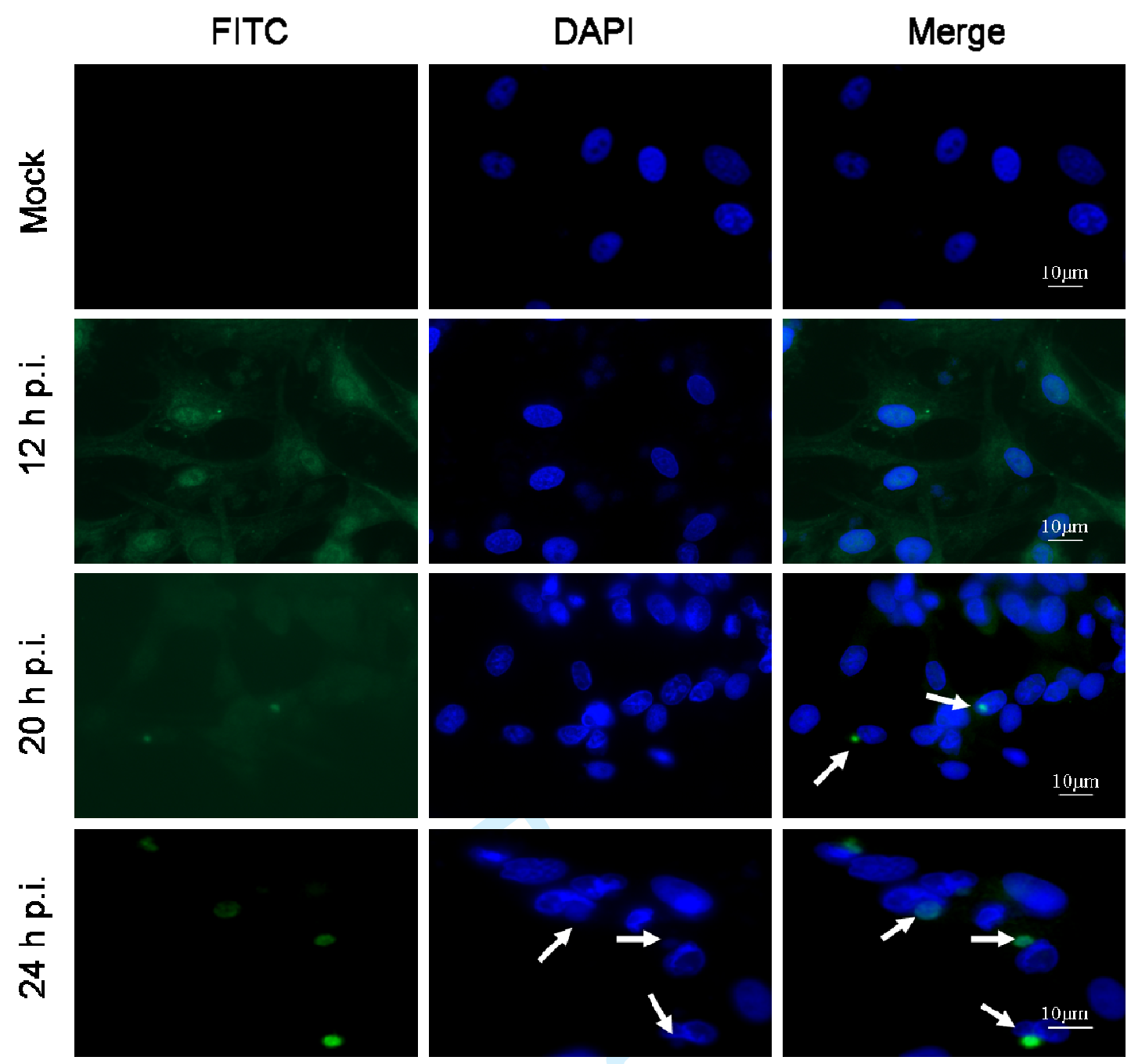


A

$$
116 \mathrm{kDa} \longrightarrow \stackrel{\mathrm{M}}{\longrightarrow} \stackrel{\mathrm{VI}}{\longrightarrow} \stackrel{\mathrm{V}}{\longrightarrow} \mathrm{E}
$$

B

1 MADNLSNVCE DFHLDPSRNP RTGKLIKEGG PVYRKLUEEC TEEGAVDVRP 51 RRGLFAEUDL DGKCDEFRRD PSRNPTTGRP IKIDGPIYKK LIRECGEETE 101 DERPRKRDMS PEEKCDEEFRR DPŚRNPITGKK TIKVGGGPYYR KLEKECSPPE 151 DTFSEASDTD FDTDYRIKLQ RKRGMSRTER CAAFDRDPTR NPITGRPIKR 201 DGPVYRRLVE DCEGDPETDD DVRUPPPRRV LDVEEKCDEF HRDPSVNPAT 251 GRPIKYGGPA FRKLLRECGD AEPRRRPLTS NEMCDEFRRD PTKNPITGRT 301 IKTGGPVHTR LLGECADDTE SEASEYAACP SRRQSUTSEE KCSAFLRDPA 351 TNPSTGKNIK EGGPTYNKLM RECSDDTSTD SDDTSEPTDR RRRRARIIGT 401 REKCEEFLEN PGINPETGKT IKHGGPYYTR LIKECAKPUS SSEISSSSDL 451 FPTQ̈EPVPLT KCQ̈KFRQNRR HNPENGKRIK KGGGPVYMRLV KECAKDDQDŚ 501 LYNVETSSDN SYTSYDMDDC FAFQRNPGIN PVTGKAIKIG GPKYKSLVKA 551 CGEPGKATMC NELENGACNI SGGTRQISDV PSSVYITEST DASSDEDYDD 601 TAYPLAVGKY TTVYGHSELT MAARHDFMKT VRUAVRDMAP SDKGFCVSG 651 RKWADNWLVS DHVVGRGSFG AVHIVQLRGL AKPVAIKESL YTSTQDKRRY 701 RPTLVWDQWV GNSEPIESKI NRLVTQTGFE RQTPFVPLTA GSGTCDSCDL 751 KLLKIQRQGR CYMQIMEPAS MSLDKVLRVM SQEQGASALA QVLLGLAALQ 801 RNLGMVHYDI KAHNVLVKKT LPGGFWAIRD SFNGQTFYVP NLGYMCMLAD 851 YGVSRLVRQS VNFSPYHGIR QCRVDVTGLA GWGDNAGKEF KITPFSTQLT 901 PELVNGVAVR IKTNKTARYW RSSENDKALH KTTYNVFSGN HDYRPSIPVD 951 LNDMARFPAW EWRGDVSWVV RMIVG̣GNRVY QSGGHHITAYA VȘKTEWELRA 1001 EKLAKANPTY SGFVLDGTGM KYVQANTAAA YIFECFRTPP PGQQLIDRYE $1051 \mathrm{~F}$
C

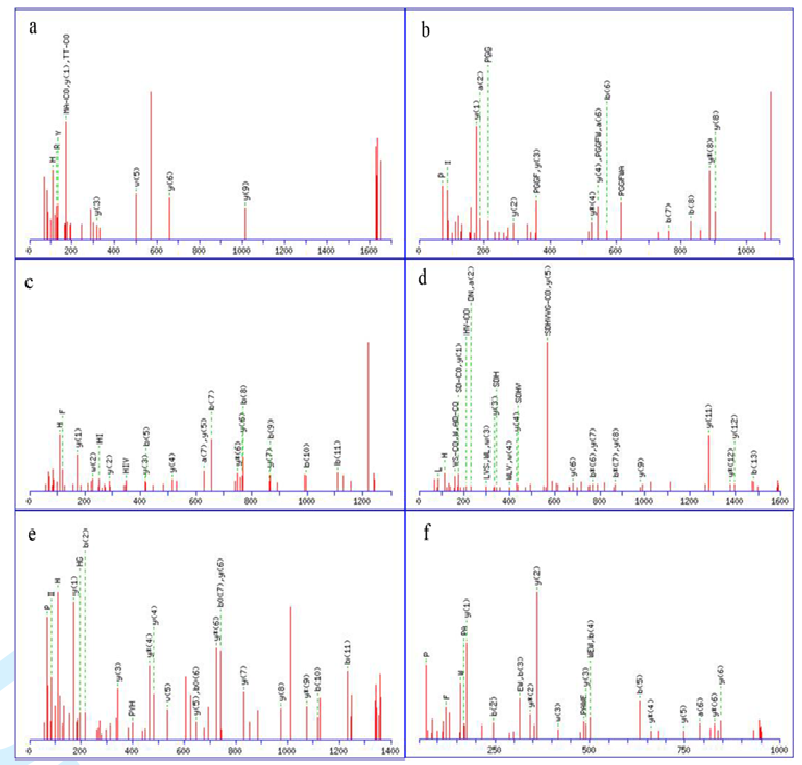



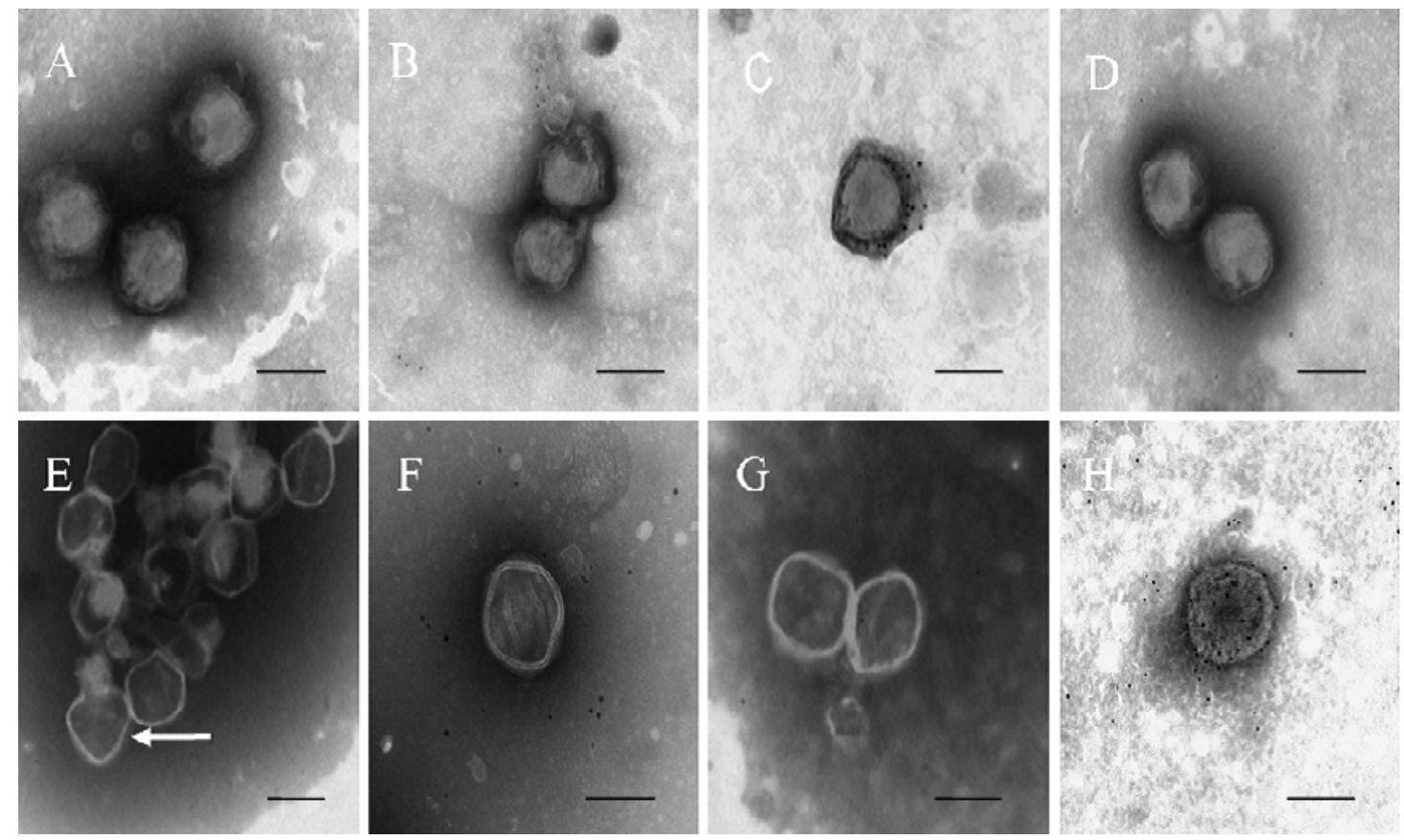


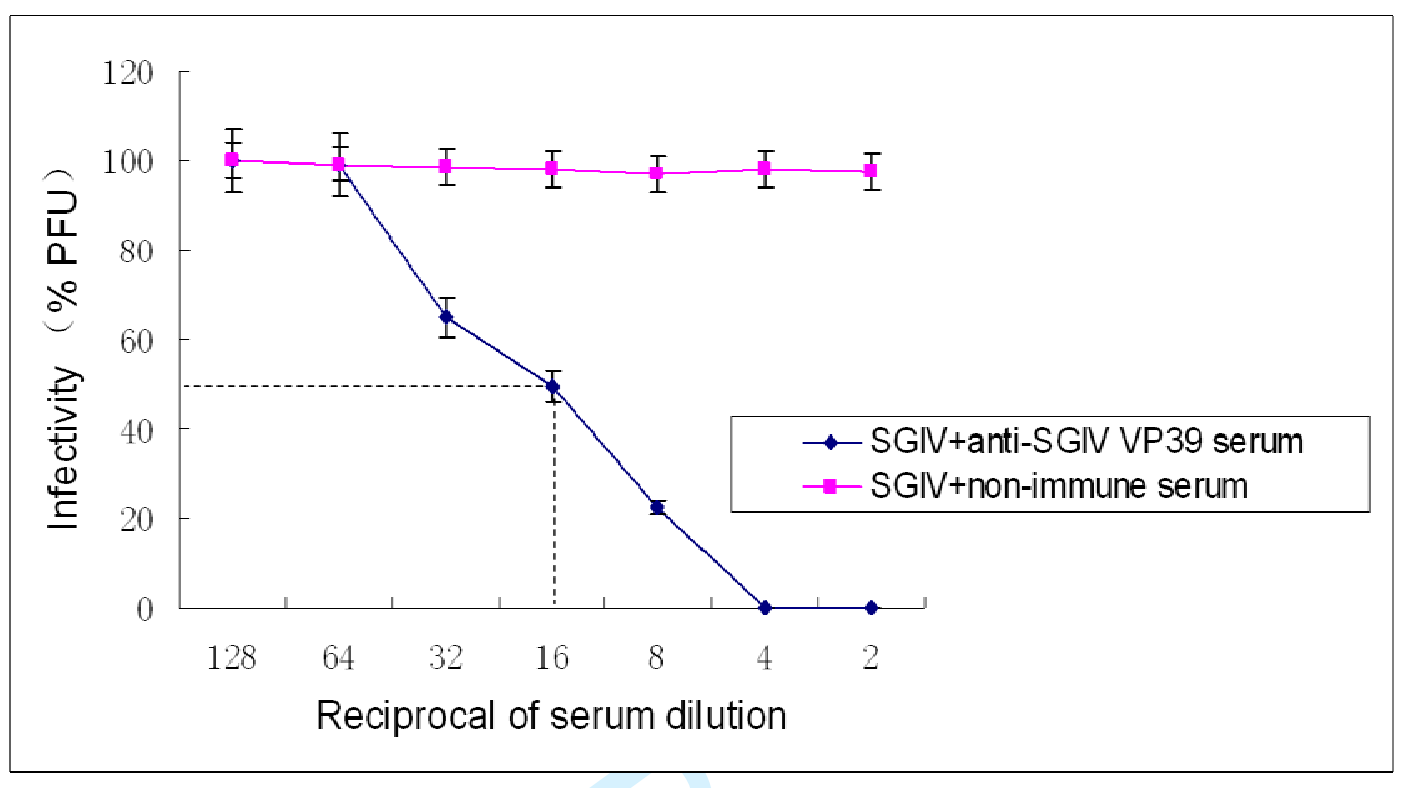

